CONCENTRATION AND

\title{
PRICE-COST MARGINS IN
}

MANUFACTURING INDUSTRIES 



\title{
CONCENTRATION AND PRICE-COST MARGINS IN MANUFACTURING INDUSTRIES
}

\author{
Norman R. Collins and \\ Lee E. Preston
}

PUBLICATIONS OF

THE INSTITUTE OF BUSINESS AND ECONOMIC RESEARCH UNIVERSTTY OF CALIFORNIA

UNIVERSITY OF CALIFORNIA PRESS

Berkeley, Los Angeles and London 1970 
University of California Press

Berkeley and Los Angeles, California

University of California Press, Ltd.

London, England

Copyright (1) 1968, by The Regents of the University of California Second Printing, 1970

ISBN 0-520-00254-7

Library of Congress Catalog Card Number: 68-63025

Printed in the United States of America 
For Dolores and Patricia 

INSTTIUTE OF BUSINESS AND ECONOMIC RESEARCH

UNIVERSITY OF CALIFORNIA, BERKELEY

Roy Radner, Chairman

Richard M. Bailey

Richard H. Holton

Daniel L. McFadden

William J. Vatter

Joseph W. Garbarino, Director

The opinions expressed in this study are those of the authors. The functions of the Institute of Business and Economic Research are confined to facilitating the prosecution of independent scholarly research by members of the faculty. 
